\title{
The roles of ebolavirus glycoproteins in viral pathogenesis
}

\author{
Yun-Jia Ning, Fei Deng, Zhihong Hu, Hualin Wang ${ }^{凶}$
}

State Key Laboratory of Virology, Wuhan Institute of Virology, Chinese Academy of Sciences, Wuhan 430071, China

\begin{abstract}
Ebolaviruses are highly dangerous pathogens exhibiting extreme virulence in humans and nonhuman primates. The majority of ebolavirus species, most notably Zaire ebolavirus, can cause Ebola virus disease (EVD), formerly known as Ebola hemorrhagic fever, in humans. EVD is associated with case-fatality rates as high as $90 \%$, and there is currently no specific treatment or licensed vaccine available against EVD. Understanding the molecular biology and pathogenesis of ebolaviruses is important for the development of antiviral therapeutics. Ebolavirus encodes several forms of glycoproteins (GPs), which have some interesting characteristics, including the transcriptional editing coding strategy and extensive O-glycosylation modification, clustered in the mucin-like domain of GP1, full-length GP $\left(\mathrm{GP}_{1,2}\right)$, and shed GP. In addition to the canonical role of the spike protein, $\mathrm{GP}_{1,2}$, in viral entry, ebolavirus GPs appear to have multiple additional functions, likely contributing to the complex pathogenesis of the virus. Here, we review the roles of ebolavirus GPs in viral pathogenesis.
\end{abstract}

\section{KEYWORDS ebolavirus; glycoprotein (GP); mucin-like domain (MLD); cytotoxicity; immune evasion; inflammation; pathogenesis}

\section{INTRODUCTION}

The 2014 Ebola epidemic in West Africa was caused by the most pathogenic ebolavirus species, EBOV (Zaire ebolavirus), and resulted in 28, 652 suspected, probable, and confirmed cases, with 11, 325 deaths as of April 13, 2016 (U.S. Centers for Disease control and Prevention, 2016a). As before the 2014 outbreak, epidemics of highly pathogenic ebolaviruses had primarily occurred sporadically in central Africa, the study of these viruses had been somewhat neglected for many years. The unprecedented and massive damage to human health and the social economy caused by the recent outbreak raised the alarm regarding the potential large-scale re-emergence of such deadly viral diseases. To date, five ebolavirus species, including Zaire ebolavirus, Sudan ebola-

Received: 3 August 2016, Accepted: 9 October 2016,

Published online: 14 November 2016

$\triangle$ Correspondence:

Phone: +86-27-87199353, Fax: +86-27-87199353,

Email: h.wang@wh.iov.cn

ORCID: 0000-0001-8916-4578 virus (Sudan virus), Bundibugyo ebolavirus (Bundibugyo virus), Taï Forest ebolavirus (Taï Forest virus), and Reston ebolavirus (Reston virus) (Bukreyev et al., 2014) have been identified. In addition to EBOV, Sudan virus, Bundibugyo virus, and Taï Forest virus are also pathogenic to humans, while human infections with Reston virus are thought to be asymptomatic (Peters and Leduc, 1999; Feldmann and Geisbert, 2011; Rougeron et al., 2015; To et al., 2015).

Although many studies of ebolavirus (particularly EBOV) have been performed using animal infection models (Nakayama and Saijo, 2013; Shurtleff and Bavari, 2015), knowledge of the pathology and pathogenesis of human ebolavirus infections remains limited. Highly pathogenic ebolavirus infections in humans and non-human primates are characterized by immune suppression and dysregulated inflammatory responses which can cause uncontrolled virus replication, immune system impairment, and tissue damage and thus likely result in the manifestations of Ebola virus disease (EVD), such as high fever, hemorrhage, disseminated intravascular coagulation, multiorgan failure, and shock (Zaki and Gold- 
smith, 1999; Mahanty and Bray, 2004; Feldmann and Geisbert, 2011; Kortepeter et al., 2011; Ansari, 2014; Chertow et al., 2014; Singh et al., 2015).

Taxonomically, ebolaviruses are enveloped, negativesense RNA viruses which belong to the genus Ebolavirus of the family Filoviridae. Ebolaviruses encode several structural proteins including the nucleoprotein (NP), virion protein 24 (VP24), VP30, VP35, VP40, polymerase (L), and full-length transmembrane glycoprotein $\left(\mathrm{GP}_{1,2}\right)$, as well as multiple nonstructural glycoproteins (GPs) such as the soluble glycoprotein (sGP), $\Delta$-peptide, small soluble glycoprotein (ssGP), and shed GP (Lee and Saphire, 2009; Cook and Lee, 2013) (Figure 1). The production of the various GP forms results from transcriptional editing (mRNA editing by the viral polymerase-mediated addition or deletion of nucleotides at the specific site) of the GP gene (Volchkov et al., 1995; Sanchez et al., 1996) and post-translational processing of GP precursors (Figure 1).

$\mathrm{GP}_{1,2}$ is the virus surface protein and forms trimeric spikes (Sanchez et al., 1998) that facilitate virus entry by mediating receptor binding and membrane fusion (Lee and Saphire, 2009). In addition to the essential role of $\mathrm{GP}_{1,2}$ as the structural protein mediating virus entry, $\mathrm{GP}_{1,2}$ as well as other GP variants have also been shown to, or are suspected to, have multiple functions in the virus life cycle and virus-host interactions, thus likely making a versatile contribution to the complex pathogenesis of ebolavirus.

Knowledge of viral protein functions and their contributions to viral pathogenesis will contribute to the development of prophylactic treatment to protect against ebolavirus infections. In this review, the function of ebolavirus GPs is briefly summarized, with a particular focus on their defined, or potential, roles in viral pathogenesis.

\section{FULL-LENGTH TRANSMEMBRANE GP $\left(\mathrm{GP}_{1,2}\right)$}

Full-length transmembrane GP $\left(\mathrm{GP}_{1,2}\right)$ is the product of the $G P$ gene with a +1 shift of the open reading frame (ORF), resulting from transcriptional editing (Volchkov et al., 1995; Sanchez et al., 1996) (Figure 1). Processing of $\mathrm{GP}_{1,2}$ in the endoplasmic reticulum (ER) and Golgi apparatus results in the generation of disulfide-linked GP1 and GP2 subunits, which are furin-cleavage products (Jeffers et al., 2002; Volchkov et al., 1998) of the full-length GP polyprotein precursor (Volchkov et al., 1998a; Volchkov, 1999; Wool-Lewis and Bates, 1999; Ito et al., 2001; Jeffers et al., 2002) (Figure 1). GP ${ }_{1,2}$ heterodimers can form trimeric structures located at the cell surface by the transmembrane domain (TMD) of GP2, or subsequently on the virus surface as virion spikes, which viruses obtain while budding from the plasma membrane (Sanchez et al., 1998; Harty et al., 2000; Han et al., 2003; Panchal et al., 2003) (Figure 1). The surface of mature $\mathrm{GP}_{1,2}$ is covered with $\mathrm{N}$ - and O-linked glycans (Jeffers et al., 2002; Ritchie et al., 2010; Lennemann et al., 2014); notably, GP1 contains a serine, threonine, and proline-rich mucin-like domain (MLD) of approximately 150 amino acid (aa) residues, which is heavily Oglycosylated at approximately 80 sites (Jeffers et al., 2002).

\section{The roles of full-length GP $\left(\mathrm{GP}_{1,2}\right)$ in the ebolavirus life cycle}

As the virion surface spikes, trimeric $\mathrm{GP}_{1,2}$ complexes mediate ebolavirus entry processes, the initial steps of viral infection, with GP1 acting as the receptor-binding subunit and GP2 as the membrane fusion subunit (Jiang et al., 2009; Lee and Saphire, 2009; Wang et al., 2011). The $\mathrm{GP}_{1,2}$-mediated entry processes and entry-associated structural and functional characterization of $\mathrm{GP}_{1,2}$ have been intensively investigated in ebolavirus and are discussed extensively elsewhere (Lee et al., 2008; Lee and Saphire, 2009; Falzarano and Feldmann, 2015; Moller-Tank and Maury, 2015; Gong et al., 2016; Tang, 2016; Wang et al., 2016; White and Whittaker, 2016). Due to its ability to bind to a variety of cell surface molecules, $\mathrm{GP}_{1,2}$ largely determines the broad cellular tropism of ebolaviruses, which can infect a wide range of cell types, including immune cells (monocytes, macrophages, and dendritic cells) and many other tissue cell types (endothelial cells, hepatocytes, adrenal cortical cells, and some epithelial cells, among others) (Feldmann and Geisbert, 2011; Takada, 2012; Martines et al., 2015; Singh et al., 2015). The infection of these cells by ebolaviruses and the resultant disturbance of normal cell physiology undoubtedly have important roles in the complicated pathogenesis of ebolavirus. For example, aside from the disorders of host immune/inflammatory responses caused by the infection of immune cells, infected monocytes, macrophages, and dendritic cells likely contribute to viral spread from the initial site of infection to regional lymph nodes, and the liver, spleen, and other tissues/organs, through the blood and lymphatic systems, especially as these immune cells are early and preferred replication sites of ebolaviruses (Schnittler and Feldmann, 1998; Geisbert et al., 2003; Bray and Geisbert, 2005). Moreover, infections in the liver, and the resulting hepatocellular necrosis, could impair synthesis of coagulation factors and other plasma proteins, contributing to the hemorrhagic tendencies observed in infected individuals, while adrenocortical infection and necrosis could damage adrenocortical function and inhibit steroid synthesis, promoting the development of hypotension, hypovolaemia, and shock that are often noted in EVD cases. 


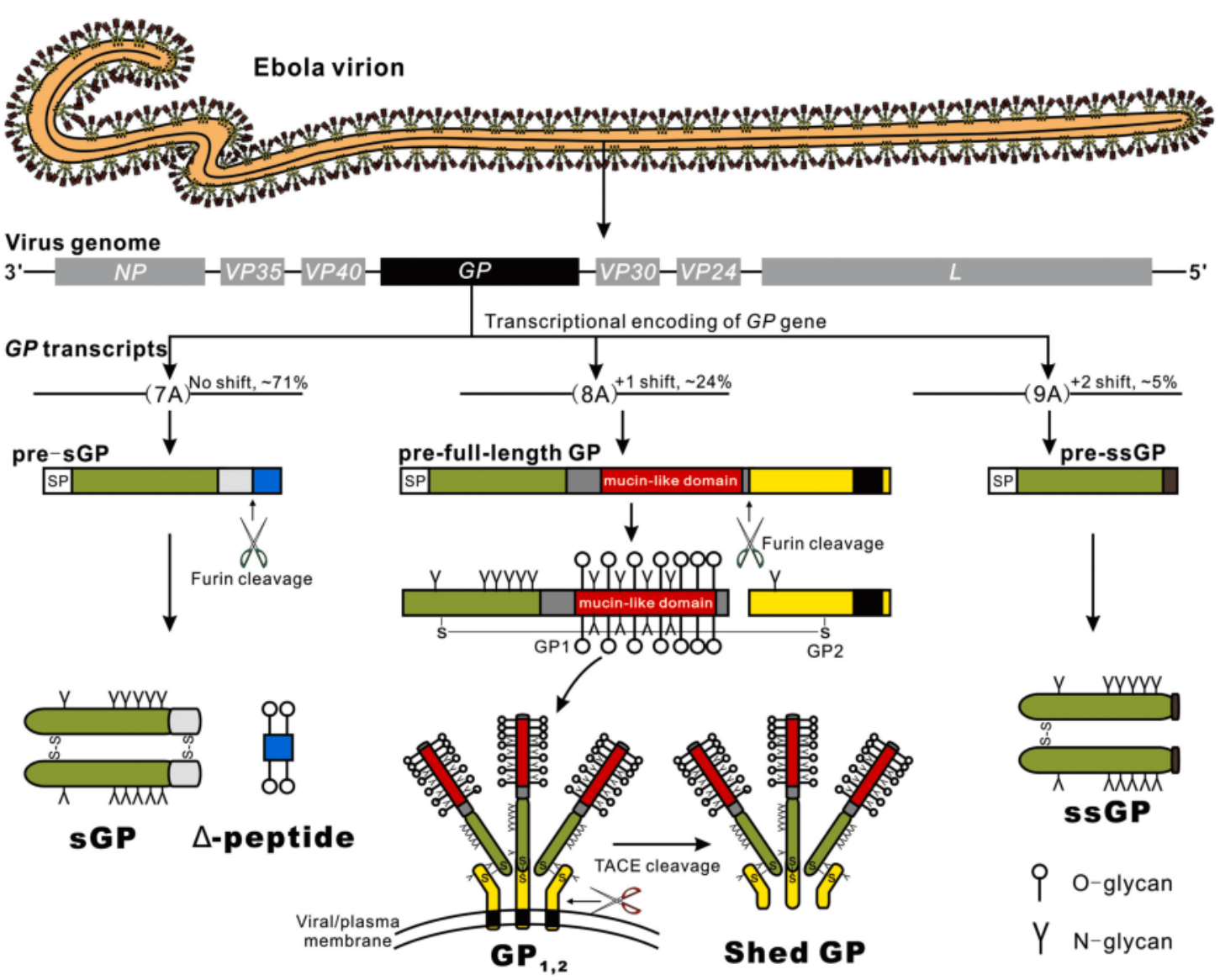

Figure 1. Encoding strategy of ebolavirus GPs. Ebolaviruses are enveloped, negative-sense RNA viruses belonging to the family Filoviridae. The ebolavirus genome contains seven genes (3'-NP-VP35-VP40-GP-VP30-VP24-L-5'), among which the GP gene encodes three GP precursors, resulting in multiple GP protein products. The primary product of the GP gene is pre-sGP, which is expressed from the majority of RNA transcripts (e.g., approximately $71 \%$ of the total transcripts in EBOV-infected Vero E6 cells) with no shift of ORF and can be cleaved by furin at its C-terminus, yielding an Nglycosylated SGP dimer and an O-glycosylated $\triangle$-peptide. Transcriptional editing can occur at a series of seven uridine residues in the GP gene, resulting in corresponding changes in the number of adenosine (A) residues in the transcripts. A +1 shift results in an extended ORF, encoding the full-length GP (approximately $24 \%$ of transcripts), while a +2 shift leads to the synthesis of the ssGP from the truncated ORF (approximately $5 \%$ of transcripts). Note that the addition of more $A$ residues or the deletion of a single $A$ nucleotide has also been observed, although transcripts containing $7 \mathrm{~A}, 8 \mathrm{~A}$, or $9 A$ at the transcriptional editing site are the most common, and encode SGP, full-length GP, or SsGP, respectively. The full-length GP precursor is cleaved by furin to form a disulfide-linked GP1-GP2 dimer, which subsequently assembles into the $\mathrm{GP}_{1,2}$ trimer and locates to the plasma or viral membrane. $\mathrm{GP}_{1,2}$ trimers on the viral membrane function as virion surface spikes, facilitating virus entry. A feature of $\mathrm{GP}_{1,2}$ is that it contains not only $\mathrm{N}$-glycans, but also extensive O-glycans, clustered in the mucin-like domain (MLD) of the GP1 subunit. As reflected in the diagram, in the native structure of GP1, the MLD (red) sits above the N-terminal domain. Some surface $\mathrm{GP}_{1,2}$ can be further cleaved by the TNF- $\alpha$ converting enzyme (TACE) at the membrane-proximal external region to release shed GP. Like sGP, mature ssGP also forms a dimer and is N-glycosylated. ssGP, full-length GP (specifically GP1), and sGP share a common Nterminus (green), but differ in their $\mathrm{C}$-termini, thus exhibiting diverse functions.

The innate immune system, and particularly the type I interferon (IFN) response, provides a stubborn line of defense in resistance to viral infections. IFN induction and signaling lead to the establishment of the host antiviral state by inducing the expression of more than 300 IFNstimulated genes which can limit viral replication and spread by targeting multiple aspects of the viral life cycle (Stark, 2007; Randall and Goodbourn, 2008; Sadler and Williams, 2008; Schneider et al., 2014; Errett and Gale, 2015). However, viruses, especially highly pathogenic hemorrhagic fever viruses, have evolved various strategies to antagonize these antiviral responses (Elliott and 
Weber, 2009; Borrow et al., 2010; Ye et al., 2013; Ning et al., 2014; Ma and Suthar, 2015; Messaoudi et al., 2015; Ning et al., 2015). VP35 and VP24 are well-known IFN antagonists of ebolaviruses (Audet and Kobinger, 2015; Basler, 2015; Messaoudi et al., 2015), and the fulllength GP also exhibits an antagonistic activity against the innate immune system by targeting tetherin, an IFNinduced antiviral factor (Van damme et al., 2008; Kaletsky et al., 2009; Tokarev et al., 2009). Tetherin is a type II transmembrane protein containing an $\mathrm{N}$-terminal TMD and a C-terminal glycosylphosphatidylinositol (GPI) membrane anchor, which is considered an unusual topology (Kupzig et al., 2003). Tetherin restricts the release of some enveloped viruses (including ebolaviruses) from infected cells by retaining virions on the cell surface through simultaneous anchoring to both the plasma membrane and the virus envelope (Jouvenet et al., 2009; Perez-Caballero et al., 2009; Tokarev et al., 2009; Fitzpatrick et al., 2010; Hammonds et al., 2010; Hinz et al., 2010; Le tortorec et al., 2011). Ebolavirus full-length GP can counteract the antiviral activity of tetherin, facilitating the completion of virus budding (Kaletsky et al., 2009). Thus, in addition to its essential roles in viral entry, full-length GP also contributes to viral budding, not only by participating in virus assembly as the structural spike glycoprotein, but also by antagonizing tetherinmediated antiviral activity. Although the mechanism underlying the antagonism of tetherin by full-length GP has not yet been clearly defined, it was reported that the ebolavirus GP does not remarkably effect the expression level of tetherin on the cell surface, or prevent the association of tetherin with lipid rafts, but may block the interaction of tetherin with VP40, a primary matrix protein with a key role in virus assembly and budding, and this may contribute to the observed antagonistic activity (Kaletsky et al., 2009; Lopez et al., 2010; Kuhl et al., 2011; Lopez et al., 2012; Gustin et al., 2015; Vande Burgt et al., 2015).

\section{The pathogenicity of full-length $\mathrm{GP}\left(\mathrm{GP}_{1,2}\right)$ and its MLD}

In addition to its pivotal contributions to the virus life cycle, the $\mathrm{GP}_{1,2}$ protein itself also exhibits notable direct pathogenicity to host cells. Expression of EBOV GP ${ }_{1,2}$ causes evident rounding and detachment of adherent cells, such as cultured human or non-human endothelial cells, epithelial cells, and macrophages (Chan et al., 2000; Takada et al., 2000; Yang et al., 2000; Simmons et al., 2002). $\mathrm{GP}_{1,2}$ from other ebolavirus species can also exert similar effects on cells, albeit at lower levels than EBOV GP ${ }_{1,2}$, paralleling the differences in virulence observed among ebolavirus species (Simmons et al., 2002). Importantly, $\mathrm{GP}_{1,2}$ expression from a replication-defective adenoviral vector induces massive endothelial cell detachment in explanted blood vessels and thus substantially increases vascular permeability (Yang et al., 2000). Interestingly, $\mathrm{EBOV} \mathrm{GP}_{1,2}$ causes endothelial disruption in both human and non-human primate blood vessels, whereas $\mathrm{GP}_{1,2}$ from Reston virus damages non-human primate but not human blood vessels, further indicating the role of $\mathrm{GP}_{1,2}$ as a virulence factor mediating vascular damage (Yang et al., 2000).

The MLD is required for $\mathrm{GP}_{1,2}$-induced toxicity to both cultured adherent cells and blood vessel explants (Yang et al., 2000; Simmons et al., 2002). In addition, cell surface expression of full-length GP, including a TMD, is needed for the $\mathrm{GP}_{1,2}$ activity; however, the requirement for a TMD does not appear to be for the specific TMD of GP2, as the toxicity of $\mathrm{GP}_{1,2}$ is maintained when the GP2 TMD is substituted with other TMDs (including those derived from influenza virus hemagglutinin, and Moloney murine leukemia virus envelope protein) (Takada et al., 2000; Yang et al., 2000). Moreover, surface expression of the MLD fused with an exogenous TMD is sufficient to induce cytopathic effects (CPE), including cell rounding and detachment (Yang et al., 2000; Francica et al., 2009).

Mechanistic studies have demonstrated that the detectable levels of cellular surface molecules, such as integrins, intercellular cell adhesion molecule-1(ICAM-1), platelet/endothelial cell adhesion molecule-1 (PECAM1), vascular cell adhesion molecule-1 (VCAM-1), epidermal growth factor receptor (EGFR), and major histocompatibility complex class I (MHC-I) appear to decrease in $\mathrm{GP}_{1,2}$-expressing cells (Takada et al., 2000; Simmons et al., 2002). Initially, it was considered that the surface expression of these molecules was down-regulated by $\mathrm{GP}_{1,2} / \mathrm{MLD}$; however, further studies suggested that MLD, acting as a "glycan umbrella", sterically shields the epitopes and functions of cellular surface proteins, rather than affecting their abundance (Reynard et al., 2009; Francica et al., 2010). Considering the significant roles of these surface proteins in physiological functions of cells, such as adhesion and immune/inflammatory signaling, $\mathrm{GP}_{1,2} / \mathrm{MLD}$-mediated cytotoxicity may contribute significantly to the inflammatory dysregulation, immune suppression, and vascular damage characteristics of ebolavirus pathogenesis.

As noted above, it is reasonable to assume that the shielding of surface molecules of endothelial cells explains $\mathrm{GP}_{1,2}$-induced endothelial CPE and vascular damage, while the functional impairment of immune cell surface proteins would interfere with the immune and inflammatory responses. Moreover, it has indeed been shown that $\mathrm{GP}_{1,2}$ expression blocks CD8+ T cell-recognition of MHC-I on antigen-presenting cells, impairing MHC-I antigen presentation (Francica et al., 2010). Steric shielding of cell surface immune molecules by the 
massive glycans of MLD is a novel mechanism of viral immune evasion. Furthermore, although antibodies can be raised against the MLD, this region is unnecessary for ebolavirus entry and highly variable compared with the other parts of the full-length GP (Wilson et al., 2000; Jeffers et al., 2002). Interestingly, MLD glycans mask antigenic epitopes of the core structure (including the receptor binding domain) of $\mathrm{GP}_{1,2}$ itself, beyond the MLD, and thereby likely blocking the activities of neutralizing antibodies, perhaps representing another MLD-mediated immune escape strategy of ebolaviruses (Lee et al., 2008; Reynard et al., 2009; Francica et al., 2010; Dias et al., 2011; Martinez et al., 2011; Cook and Lee, 2013; Misasi et al., 2016; Pallesen et al., 2016).

In addition to the MLD, a putative immunosuppressive domain (ISD) close to the $\mathrm{C}$-terminus of $\mathrm{GP}_{1,2}$ may also contribute to viral immune suppression by inhibiting $\mathrm{T}$ cell cycle progression and inducing $\mathrm{T}$ cell apoptosis, thus likely promoting the lymphocyte depletion observed in severe infections (Volchkov et al., 1992; Becker, 1995; Baize et al., 1999; Zaki and Goldsmith, 1999; Geisbert et al., 2000; Yaddanapudi et al., 2006).

Clinically, ebolavirus infection is typified by an exaggerated inflammatory response resembling septic shock (Zaki and Goldsmith, 1999; Baize et al., 2002; Cilloniz et al., 2011; Feldmann and Geisbert, 2011; Kortepeter et al., 2011; Ansari, 2014; Singh et al., 2015). Several studies have suggested that $\mathrm{GP}_{1,2}$, and in particular the MLD, are likely involved in activation of the inflammatory response (Wahl-Jensen et al., 2005a; Ye et al., 2006; Martinez et al., 2007; Okumura et al., 2010). Virus-like particles (VLPs) harboring $\mathrm{GP}_{1,2}$ can activate dendritic cells and macrophages and trigger the secretion of inflammatory cytokines, such as tumor necrosis factor- $\alpha$ (TNF- $\alpha$ ), interleukin-6 (IL-6), IL-8, IFN--inducible protein-10 (IP-10), and the chemokine RANTES (regulated upon activation normal $\mathrm{T}$ cell expressed and secreted) (Bosio et al., 2004; Wahl-Jensen et al., 2005a; Ye et al., 2006; Martinez et al., 2007; Okumura et al., 2010). Functional studies further demonstrate that $\mathrm{GP}_{1,2}$ on VLPs simulates the activation of NF- $\mathrm{kB}$ and elicits inflammatory cytokine production via the toll-like receptor-4 (TLR4) signaling pathway. Moreover, MLD is also indispensable for the activity of $\mathrm{GP}_{1,2}$ (Martinez et al., 2007; Okumura et al., 2010). In addition to TLR4, the liver and lymph node sinusoidal endothelial cell C-type lectin (LSECtin) may also be involved in $\mathrm{GP}_{1,2}$-triggered pro-inflammatory cytokine production in dendritic cells, by recognizing $\mathrm{GP}_{1,2}$ as an additional pattern recognition receptor and activating $12 \mathrm{kDa} \mathrm{DNAX}$-activating protein (DAP12)-Syk signaling (Zhao et al., 2016). These effects, mediated by $\mathrm{GP}_{1,2}$, are likely involved in the excessive and dysregulated inflammatory reactions elicited to ebolavirus infection, and thus likely also contribute to viral pathogenicity.

\section{SHED GP}

Shed GP is a product of the proteolytic cleavage of cell surface $\mathrm{GP}_{1,2}$ by TNF- $\alpha$-converting enzyme (TACE) (Dolnik et al., 2004) (Figure 1). Shed GP is released from the cell surface in significant amounts in a soluble trimeric form (Dolnik et al., 2004). The proteolytic cleavage results in the removal of a short transmembrane anchor from the GP2 subunit of $\mathrm{GP}_{1,2}$ (Figure 1). Due to the preservation of its antigenic properties, shed GP can be recognized by anti-GP ${ }_{1,2}$ antibodies and exhibits a decoy function, sequestering anti-GP ${ }_{1,2}$ antibodies that would otherwise bind to $\mathrm{GP}_{1,2}$, and potentially induce the elimination of viruses and infected cells (Dolnik et al., 2004).

Recently, shed GP was shown to trigger the activation of non-infected dendritic cells and macrophages, leading to profuse expression of inflammatory cytokines, in a similar manner to $\mathrm{GP}_{1,2}$, (Escudero-Perez et al., 2014). Interestingly, anti-TLR4 antibodies can efficiently block shed GP-mediated activation of immune cells; moreover, treatment of shed GP with either deglycosylases or mannose-binding lectin can inhibit the activity of shed GP (Escudero-Perez et al., 2014). These results suggest that cellular TLR4 signaling and shed GP surface glycans are likely involved in the inflammatory activation associated with ebolavirus infection. In addition, like $\mathrm{GP}_{1,2}$, shed GP may also activate LSECtin signaling and trigger pro-inflammatory cytokine secretion by dendritic cells (Zhao et al., 2016).

Furthermore, treatment of HUVEC monolayers with shed GP increases their permeability, indicating a direct effect of shed GP in damage of the endothelial barrier (Zhao et al., 2016). Combined with the significant activities of some inflammatory cytokines, particularly TNF- $\alpha$ (Wahl-Jensen et al., 2005b), in impairment of endothelial barrier integrity, these data suggest that the disruption of endothelial barriers can be mediated directly by shed GP itself, by an unknown mechanism, or indirectly by shed GP-induced inflammatory cytokines (Escudero-Perez et al., 2014).

Additionally, aside from the RNA-editing strategy for regulation of GP expression (Volchkov et al., 2001), the release of shed GP may be another mechanism to modulate the abundance of cell surface $\mathrm{GP}_{1,2}$, and hence virion $\mathrm{GP}_{1,2}$ content and cytotoxicity, and this process likely has a role in orchestrating optimal ebolavirus infectivity and spread (Dolnik et al., 2015; Mohan et al., 2015).

\section{SOLUBLE GLYCOPROTEIN (sGP)}

sGP, the primary product of the $G P$ gene, is expressed from transcripts with no reading frame shift and is initially synthesized as pre-sGP (Volchkov et al., 1995; 
Sanchez et al., 1996; Volchkova et al., 1999) (Figure 1). Pre-sGP then undergoes post-translational proteolytic cleavage and glycosylation, yielding mature sGP and a $\Delta$-peptide (Volchkova et al., 1999) (Figure 1). sGP monomers can be dimerized in a parallel orientation to form a $110 \mathrm{kDa}$ homodimer (Barrientos et al., 2004; Falzarano et al., 2006; Pallesen et al., 2016) (Figure 1). Both sGP and $\Delta$-peptide can be secreted extracellularly, while $\Delta$-peptide is retained in producer cells for a longer period than sGP (Volchkova et al., 1999).

Previous studies have suggested that sGP may exhibit versatile immunomodulatory functions (Kindzelskii et al., 2000; Ito et al., 2001; Sui and Marasco, 2002; WahlJensen et al., 2005b; Mohan et al., 2012; de La Vega et al., $2015)$. Since sGP is the main product of the GP gene and shares a common $\mathrm{N}$-terminus ( 295 aa residues) with fulllength GP, it was hypothesized that, like shed GP, sGP acts as a decoy antigen by adsorbing the antibodies against $\mathrm{GP}_{1,2}$, thus counteracting antibody-mediated clearance of viral infection (Wilson et al., 2000; Ito et al., 2001). Furthermore, a model of sGP-mediated "antigenic subversion" was proposed, which postulated that the much higher quantity of sGP may lead to sGP domination of host humoral responses, and divert the immune response away from $\mathrm{GP}_{1,2}$ (Mohan et al., 2012).

sGP may also exhibit some anti-inflammatory activities, including inactivation of neutrophils and partial restoration of the TNF- $\alpha$-induced decrease of the barrier function of endothelial cells (Kindzelskii et al., 2000; Sui and Marasco, 2002; Wahl-Jensen et al., 2005b), although the molecular mechanisms underlying these phenomena have not yet been determined.

In addition to being extracellularly secreted as a nonstructural protein, sGP appears to be able to assemble with GP2 as a substitute for GP1 and, intriguingly, the sGP-GP2 complex can also mediate infection in a vesicular stomatitis virus (VSV) pseudotype model, indicating a potential role for sGP as a structural protein (Iwasa et al., 2011). However, the biological significance of the replacement of GP1 by sGP in $\mathrm{GP}_{1,2}$ has yet to be determined.

\section{$\triangle$-PEPTIDE}

$\Delta$-peptide was first described by Volchkova et al. during the course of an investigation of the processing and maturation of sGP (Volchkova et al., 1999). sGP is N-glycosylated, while $\Delta$-peptide is O-glycosylated (Volchkova et al., 1999) (Figure 1). The production of $\Delta$-peptide is conserved across all ebolavirus species, suggesting an important role (or roles) for the peptide.

Radoshitzky et al. reported that $\Delta$-peptides of several pathogenic ebolaviruses (EBOV, Sudan virus, and Taï
Forest virus) can efficiently bind to filovirus-permissive cells and inhibit Marburg virus (MARV, another filovirus) and ebolavirus $\mathrm{GP}_{1,2}$-mediated cell entry (Radoshitzky et al., 2011), even though MARV does not produce $\Delta$-peptides. In contrast, the $\Delta$-peptide of Reston virus exhibits less-efficient cell binding and no obvious inhibitory effect on cell entry of filoviruses, indicating a potential role for $\Delta$-peptide in determining viral virulence (Radoshitzky et al., 2011). Suppression of ebolavirus entry by $\Delta$-peptide, which is a post-infection product, may prevent virus superinfection and thereby benefit viral spread and systematic infection. Although the mechanism of $\Delta$ peptide-mediated inhibition of filovirus infection remains unclear, the impairment of cell entry of both MARV and ebolaviruses by $\Delta$-peptides suggests that these peptides probably interfere with a common pathway involved in filovirus entry (Radoshitzky et al., 2011).

Recently, Gallaher and Garry performed sequence analyses and computational modeling to identify a conserved amphipathic region in the $\Delta$-peptides of filoviruses (particularly EBOV) with high similarity to the cytolytic peptide motif of rotavirus nonstructural protein 4 (NSP4) (Gallaher and Garry, 2015). The authors hypothesized that $\Delta$-peptides may serve as membrane-damaging viroporins, thus contributing to ebolavirus pathogenesis (Gallaher and Garry, 2015). The membrane-association potential of $\Delta$-peptides may explain the retention of $\Delta$-peptides in cells after secretion of the bulk of sGP has occurred (Gallaher and Garry, 2015); nevertheless, whether $\Delta$-peptides exhibit such biological functions requires experimental verification.

\section{SMALL SOLUBLE GLYCOPROTEIN (sSGP)}

The existence of ssGP, which is encoded by the +2 -shift reading frame of the GP gene, had long been postulated before being experimentally verified by Mehedi et al. (Mehedi et al., 2011). The similar molecular masses of sGP and ssGP, the low abundance of ssGP (encoded by $<5 \%$ of $G P$ transcripts) (Figure 1), and the lack of ssGPspecific antibodies make the detection of ssGP expression difficult by conventional methodology (Mehedi et al., 2011). To date, the function of ssGP is unknown. ssGP is essentially a truncated form of sGP and the two proteins share an identical N-terminal sequence (295 aa) (Figure 1). Moreover, mature ssGP is extensively Nglycosylated and forms homodimers, in the same way as sGP (Mehedi et al., 2011) (Figure 1). However, despite similarities in the biochemical properties and primary sequences of sGP and ssGP, ssGP does not demonstrate the anti-inflammatory activity exhibited by sGP that reverses TNF- $\alpha$-induced loss of endothelial barrier function (Mehedi et al., 2011; Wahl-Jensen et al., 2005b). 


\section{CONCLUSION}

Underestimating highly virulent pathogens, such as EBOV, would be immensely costly to society. The 2014
Ebola outbreak not only resulted in devastating health effects and pronounced socio-economic impacts in West Africa, but also caused a global panic, particularly with the occurrence of imported Ebola cases in countries out-

Table 1. Summary of the known or potential functions of ebolavirus GPs

\begin{tabular}{|c|c|c|}
\hline GPs & Functions & References \\
\hline \multirow[t]{6}{*}{ Full-length GP $\left(\mathrm{GP}_{1,2}\right)$} & Mediates virus entry as the virion surface spike & Lee and Saphire., 2009 \\
\hline & Promotes virus budding by antagonizing tetherin & Kaletsky et al., 2009 \\
\hline & $\begin{array}{l}\text { Sterically shields the epitopes and functions of cellular surface } \\
\text { proteins via the MLD, causing rounding and detachment of cultured } \\
\text { cells, endothelial cell damage, leakage of explanted blood vessels, } \\
\text { and loss of cell physiological functions (such as antigen presentation } \\
\text { by MHC-I) }\end{array}$ & $\begin{array}{l}\text { Chan et al., 2000; } \\
\text { Takada et al., 2000; } \\
\text { Yang et al., 2000; } \\
\text { Simmons et al., 2002; } \\
\text { Reynard et al., 2009; } \\
\text { Francica et al., } 2010\end{array}$ \\
\hline & $\begin{array}{l}\text { Sterically shields the epitopes of the } \mathrm{GP}_{1,2} \text { core via the MLD, } \\
\text { blocking recognition by neutralizing antibodies (?) }\end{array}$ & $\begin{array}{l}\text { Reynard et al., 2009; } \\
\text { Francica et al., } 2010\end{array}$ \\
\hline & $\begin{array}{l}\text { Activates MФ/DCs and triggers the secretion of inflammatory } \\
\text { cytokines by the MLD (?), likely contributing to the excessive } \\
\text { inflammation in EVD }\end{array}$ & $\begin{array}{l}\text { Wahl-Jensen et al., 2005a; } \\
\text { Ye et al., 2006; } \\
\text { Martinez et al., } 2007\end{array}$ \\
\hline & Contains a putative ISD, mediating T cell dysfunction/apoptosis (?) & $\begin{array}{l}\text { Volchkov et al., 1992; } \\
\text { Yaddanapudi et al., } 2006\end{array}$ \\
\hline \multirow[t]{4}{*}{ Shed GP } & $\begin{array}{l}\text { Functions as a decoy for anti-GP } \mathrm{G}_{1,2} \text { antibodies, contributing to viral } \\
\text { immune evasion }\end{array}$ & Dolnik et al., 2004 \\
\hline & $\begin{array}{l}\text { Activates MФ/DCs leading to the secretion of inflammatory } \\
\text { cytokines; increases the permeability of HUVEC monolayers }\end{array}$ & Escudero-Perez et al., 2014 \\
\hline & $\begin{array}{l}\text { Its release modulates the abundance of surface } \mathrm{GP}_{1,2} \text {, likely } \\
\text { orchestrating virus cytotoxicity, infectivity, and spread (?) }\end{array}$ & Dolnik et al., 2015 \\
\hline & Contains a putative ISD, mediating T cell dysfunction/apoptosis (?) & $\begin{array}{l}\text { Volchkov et al., 1992; } \\
\text { Yaddanapudi et al., } 2006\end{array}$ \\
\hline \multirow[t]{3}{*}{ sGP } & $\begin{array}{l}\text { Functions as a decoy of anti-GP } \mathrm{P}_{1,2} \text { antibodies, or mediates } \\
\text { "antigenic subversion", diverting the immune response away } \\
\text { from } \mathrm{GP}_{1,2}(?)\end{array}$ & $\begin{array}{l}\text { Wilson et al., } 2000 \text {; } \\
\text { Ito et al., } 2001 \text {; } \\
\text { Mohan et al., } 2012\end{array}$ \\
\hline & $\begin{array}{l}\text { Inactivates neutrophils and reverses TNF-a-induced injury of } \\
\text { endothelial barriers, playing anti-inflammatory roles (?) }\end{array}$ & $\begin{array}{l}\text { Kindzelskii et al., 2000; } \\
\text { Sui and Marasco., 2002; } \\
\text { Wahl-Jensen et al., 2005b }\end{array}$ \\
\hline & $\begin{array}{l}\text { Assembles with GP2 as a substitute for GP1, perhaps as a } \\
\text { structural protein (?) }\end{array}$ & Iwasa et al., 2011 \\
\hline \multirow[t]{2}{*}{$\Delta$-peptide } & $\begin{array}{l}\text { Binds to filovirus-permissive cells and inhibits filovirus } \\
\mathrm{GP}_{1,2} \text {-mediated cell entry }\end{array}$ & Radoshitzky et al., 2011 \\
\hline & $\begin{array}{l}\text { Contains an amphipathic region similar to the cytolytic peptide } \\
\text { motif of rotavirus NSP4 and may serve as a membrane- } \\
\text { damaging viroporin (?) }\end{array}$ & Gallaher and Garry., 2015 \\
\hline ssGP & $\begin{array}{l}\text { Unknown; unlike sGP, does not display the anti-inflammatory } \\
\text { activity that reverses TNF-a-induced damage of endothelial } \\
\text { barriers }\end{array}$ & Mehedi et al., 2011 \\
\hline
\end{tabular}

Notes: GP, glycoprotein; GPs, glycoproteins; sGP, soluble glycoprotein; ssGP, small soluble glycoprotein; MLD, mucin-like domain; MHC-I, major histocompatibility complex class I; MФ, macrophages; DCs, dendritic cells; EVD, Ebola virus disease; ISD, immunosuppressive domain; HUVEC, human umbilical vein endothelial cell; TNF- $\alpha$, tumor necrosis factor- $\alpha$; NSP4, nonstructural protein 4; "(?)" indicates putative functions that especially require additional verification. 
side of Africa (U.S. Centers for Disease contrOl and Prevention, 2016b). Effective preventive and therapeutic methods are urgently needed to tackle this virus. Considering their essential roles in virus entry and multifaceted functions in viral pathogenesis (summarized in Table 1),
GPs (especially $\mathrm{GP}_{1,2}$ ) of ebolaviruses are important, and potentially preferred targets, for the prevention and treatment of ebolavirus infections, for example as targets for potential therapeutic antibodies (Qiu et al., 2014; Bornholdt et al., 2016; Corti et al., 2016; Furuyama et

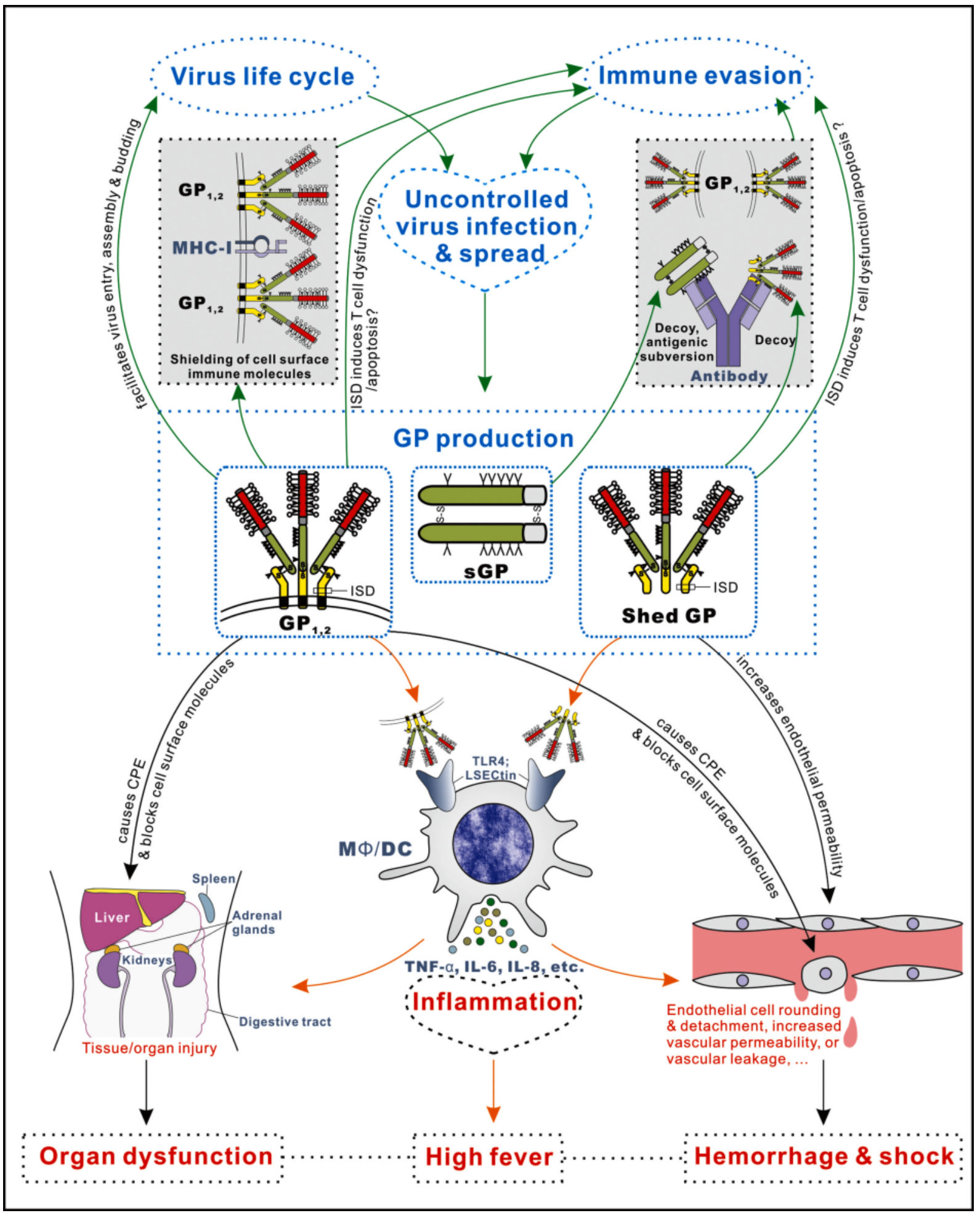


Figure 2. Model for the roles of $\mathrm{GP}_{1,2}$, shed GP, and sGP in ebolavirus pathogenesis. $\mathrm{GP}_{1,2}$, shed GP, and sGP constitute the main GP products of ebolaviruses and are more fully characterized functionally than other GPs. Severe ebolavirus infections are typified by uncontrolled virus infection and spread, and systemic inflammation, to which $\mathrm{GP}_{1,2}$, shed GP, and SGP likely contribute in various ways. In addition to the essential roles of $\mathrm{GP}_{1,2}$ in the virus life cycle of facilitating virus entry and assembly, all three GPs are involved in virus immune escape, leading to uncontrolled disseminated virus replication and consequent increased GP production. $\mathrm{GP}_{1,2}$ antagonizes tetherin to promote virus budding, mediates steric blocking of cell surface immune molecules (such as $\mathrm{MHC}-\mathrm{I}$ ) and perhaps the $\mathrm{GP}_{1,2}$ core via the extensively O-glycosylated MLD, and may induce $T$ cell dysfunction/apoptosis via the putative immunosuppressive domain (ISD) adjacent to the TACE cleavage site (indicated by a box). Shed GP retains the ISD and thus has the potential capacity to target $\mathrm{T}$ cells. Shed GP and sGP may both inhibit anti-GP ${ }_{1,2}$ antibody-mediated clearance of viral infection by acting as decoy antigens. Moreover, sGP may also exert the same effect by inducing "antigenic subversion". On the other hand, $\mathrm{GP}_{1,2}$ and shed GP both activate macrophages $(M \Phi)$ and dendritic cells (DCs) and induce inflammatory cytokine secretion by triggering TLR4 and LSECtin signaling pathways. In addition, $\mathrm{GP}_{1,2}$ directly induces CPE, including cell rounding and detachment, and impairs cell physiological functions by blocking cell surface molecules with the MLD, leading to endothelial damage and vascular leakage and other tissue/organ injury. Shed GP can also directly cause increased endothelial permeability by an undefined mechanism. Both the direct toxicity of $\mathrm{GP}_{1,2}$ and shed GP, and their inflammation-mediated pathogenic characteristics, may eventually contribute to the clinical manifestations of EVD, such as fever, hemorrhage, shock, and multi-organ dysfunction.

al., 2016; Howell et al., 2016; Misasi et al., 2016; Pallesen et al., 2016; Wec et al., 2016). Among the GP variants, $\mathrm{sGP}, \mathrm{GP}_{1,2}$, and shed GP are the main viral GP products and their functional roles are more fully characterized. We propose a model for the critical roles of $\mathrm{GP}_{1,2}$, shed GP, and sGP in virus infection and pathogenesis, which is summarized in Figure 2. In addition to the direct roles of $\mathrm{GP}_{1,2}$ in the virus life cycle, the three GP variants are all believed to contribute to ebolavirus immune evasion by multiple strategies, thus contributing to uncontrolled virus infection and spread (Figure 2). Moreover, $\mathrm{GP}_{1,2}$ and shed GP may also promote pathological lesions and the development of clinical manifestations of EVD such as high fever, hemorrhage, shock, and organ dysfunction, by their direct effects (such as cytotoxicity) and the indirect effects induced by excessive inflammation (Figure 2).

Despite the important achievements of studies of ebolavirus GPs, many key facets of the functions of these proteins remain to be elucidated. For example, although many investigations have indicated that $\mathrm{GP}_{1,2}$ can induce cytotoxicity and vascular damage, to date there is no in vivo data verifying these roles of $\mathrm{GP}_{1,2}$. The physiological relevance of the observed functions of GPs in vitro needs to be further investigated in vivo using animal models, along with various GP gene-engineered recombinant ebolaviruses (Groseth et al., 2012). Functional and structural studies of the soluble GPs, especially ssGP and $\Delta$-peptide, are relatively scarce, compared with those of $\mathrm{GP}_{1,2}$. In addition to $\mathrm{GP}_{1,2}$ and the soluble GPs discussed above, other products of the GP gene have also been identified (Sanchez et al., 1998; Volchkov et al., 1998b); these include the short transmembrane anchor remaining after the release of shed GP, secreted GP1 (separate from GP2), and lone GP2. Whether these pro- teins are merely by-products of the $G P$ gene or have significant biological functions requires further investigation.

Since the majority of studies of ebolaviruses have focused on EBOV, the molecular biology and pathogenesis of ebolaviruses are best characterized for this species; however, we consider that the notable variation in the virulence of different ebolavirus species provides an opportunity to unravel viral pathogenesis, and that comparative studies of different species and diverse hosts would be of interest and are merited. Additionally, insights from ebolaviruses will be valuable in enabling better understanding of the biology and pathogenesis of other pathogens causing hemorrhagic fever, such as MARV and Crimean-Congo hemorrhagic fever virus (a bunyavirus), which also encode GPs with a heavily O-glycosylated MLD (Sanchez et al., 2006; Wertheim and Worobey, 2009). It is reasonable and interesting to hypothesize that these GPs and MLDs may play similar significant roles in the virulence and pathogenesis of these various pathogens.

\section{ACKNOWLEDGMENTS}

This work was supported by the National Natural Science Foundation of China (No. 31125003 and No. 31321001) and the Basic Work Program of the Ministry of Science and Technology of China (2013FY113500).

\section{COMPLIANCE WITH ETHICS GUIDELINES}

The authors declare that they have no conflicts of interest. This article does not contain any studies with human or animal subjects performed by any of the authors. 


\section{OPEN ACCESS}

This article is distributed under the terms of the Creative Commons Attribution 4.0 International License (http://creative commons.org/licenses/by/4.0/), which permits unrestricted use, distribution, and reproduction in any medium, provided you give appropriate credit to the original author(s) and the source, provide a link to the Creative Commons license, and indicate if changes were made.

\section{REFERENCES}

Ansari AA. 2014. Clinical features and pathobiology of Ebolavirus infection. J Autoimmun, 55: 1-9.

Audet J, Kobinger GP. 2015. Immune evasion in ebolavirus infections. Viral Immunol, 28: 10-18.

Baize S, Leroy EM, Georges-Courbot MC, Capron M, LansoudSoukate J, Debre P, Fisher-Hoch SP, McCormick JB, Georges AJ. 1999. Defective humoral responses and extensive intravascular apoptosis are associated with fatal outcome in Ebola virusinfected patients. Nat Med, 5: 423-426.

Baize S, Leroy EM, Georges AJ, Georges-Courbot MC, Capron M, Bedjabaga I, Lansoud-Soukate J, Mavoungou E. 2002. Inflammatory responses in Ebola virus-infected patients. Clin Exp Immunol, 128: 163-168.

Barrientos LG, Martin AM, Rollin PE, Sanchez A. 2004. Disulfide bond assignment of the Ebola virus secreted glycoprotein SGP. Biochem Biophys Res Commun, 323: 696-702.

Basler CF. 2015. Innate immune evasion by filoviruses. Virology, 479-480: 122-130.

Becker Y. 1995. Retrovirus and filovirus "immunosuppressive motif" and the evolution of virus pathogenicity in HIV-1, HIV2, and Ebola viruses. Virus Genes, 11: 191-195.

Bornholdt ZA, Turner HL, Murin CD, Li W, Sok D, Souders CA, Piper AE, Goff A, Shamblin JD, Wollen SE, Sprague TR, Fusco ML, Pommert KB, Cavacini LA, Smith HL, Klempner M, Reimann KA, Krauland E, Gerngross TU, Wittrup KD, Saphire EO, Burton DR, Glass PJ, Ward AB, Walker LM. 2016. Isolation of potent neutralizing antibodies from a survivor of the 2014 Ebola virus outbreak. Science, 351: 1078-1083.

Borrow P, Martinez-Sobrido L, de la Torre JC. 2010. Inhibition of the type I interferon antiviral response during arenavirus infection. Viruses, 2: 2443-2480.

Bosio CM, Moore BD, Warfield KL, Ruthel G, Mohamadzadeh M, Aman MJ, Bavari S. 2004. Ebola and Marburg virus-like particles activate human myeloid dendritic cells. Virology, 326: 280-287.

Bray M, Geisbert TW. 2005. Ebola virus: the role of macrophages and dendritic cells in the pathogenesis of Ebola hemorrhagic fever. Int J Biochem Cell Biol, 37: 1560-1566.

Bukreyev AA, Chandran K, Dolnik O, Dye JM, Ebihara H, Leroy EM, Muhlberger E, Netesov SV, Patterson JL, Paweska JT, Saphire EO, Smither SJ, Takada A, Towner JS, Volchkov VE, Warren TK, Kuhn JH. 2014. Discussions and decisions of the 2012-2014 International Committee on Taxonomy of Viruses (ICTV) Filoviridae Study Group, January 2012-June 2013. Arch Virol, 159: 821-830.

Chan SY, Ma MC, Goldsmith MA. 2000. Differential induction of cellular detachment by envelope glycoproteins of Marburg and Ebola (Zaire) viruses. J Gen Virol, 81: 2155-2159.
Chertow DS, Kleine C, Edwards JK, Scaini R, Giuliani R, Sprecher A. 2014. Ebola virus disease in West Africa--clinical manifestations and management. N Engl J Med, 371: 2054-2057.

Cilloniz C, Ebihara H, Ni C, Neumann G, Korth MJ, Kelly SM, Kawaoka Y, Feldmann H, Katze MG. 2011. Functional genomics reveals the induction of inflammatory response and metalloproteinase gene expression during lethal Ebola virus infection. $\mathrm{J}$ Virol, 85: 9060-9068.

Cook JD, Lee JE. 2013. The secret life of viral entry glycoproteins: moonlighting in immune evasion. PLoS Pathog, 9: e1003258.

Corti D, Misasi J, Mulangu S, Stanley DA, Kanekiyo M, Wollen S, Ploquin A, Doria-Rose NA, Staupe RP, Bailey M, Shi W, Choe M, Marcus H, Thompson EA, Cagigi A, Silacci C, Fernandez-Rodriguez B, Perez L, Sallusto F, Vanzetta F, Agatic G, Cameroni E, Kisalu N, Gordon I, Ledgerwood JE, Mascola JR, Graham BS, Muyembe-Tamfun JJ, Trefry JC, Lanzavecchia A, Sullivan NJ. 2016. Protective monotherapy against lethal Ebola virus infection by a potently neutralizing antibody. Science, 351: 1339-1342.

de La Vega MA, Wong G, Kobinger GP, Qiu X. 2015. The multiple roles of sGP in Ebola pathogenesis. Viral Immunol, 28: 3-9.

Dias JM, Kuehne AI, Abelson DM, Bale S, Wong AC, Halfmann P, Muhammad MA, Fusco ML, Zak SE, Kang E, Kawaoka Y, Chandran K, Dye JM, Saphire EO. 2011. A shared structural solution for neutralizing ebolaviruses. Nat Struct Mol Biol, 18: 1424-1427.

Dolnik O, Volchkova V, Garten W, Carbonnelle C, Becker S, Kahnt R, Stroher U, Klenk HD, Volchkov V. 2004. Ectodomain shedding of the glycoprotein GP of Ebola virus. Embo Journal, 23: 2175-2184.

Dolnik O, Volchkova VA, Escudero-Perez B, Lawrence P, Klenk HD, Volchkov VE. 2015. Shedding of Ebola Virus Surface Glycoprotein Is a Mechanism of Self-regulation of Cellular Cytotoxicity and Has a Direct Effect on Virus Infectivity. J Infect Dis, 212 Suppl 2: S322-328.

Elliott RM, Weber F. 2009. Bunyaviruses and the type I interferon system. Viruses, 1: 1003-1021.

Errett JS, Gale M. 2015. Emerging complexity and new roles for the RIG-I-like receptors in innate antiviral immunity. Virol Sin, 30: $163-173$.

Escudero-Perez B, Volchkova VA, Dolnik O, Lawrence P, Volchkov VE. 2014. Shed GP of Ebola virus triggers immune activation and increased vascular permeability. PLoS Pathog, 10: e1004509.

Falzarano D, Feldmann H. 2015. Virology. Delineating Ebola entry. Science, 347: 947-948.

Falzarano D, Krokhin O, Wahl-Jensen V, Seebach J, Wolf K, Schnittler HJ, Feldmann H. 2006. Structure-function analysis of the soluble glycoprotein, sGP, of Ebola virus. Chembiochem, 7: $1605-1611$.

Feldmann H, Geisbert TW. 2011. Ebola haemorrhagic fever. Lancet, 377: 849-862.

Fitzpatrick K, Skasko M, Deerinck TJ, Crum J, Ellisman MH, Guatelli J. 2010. Direct restriction of virus release and incorporation of the interferon-induced protein BST-2 into HIV-1 particles. PLoS Pathog, 6: e1000701.

Francica JR, Matukonis MK, Bates P. 2009. Requirements for cell rounding and surface protein down-regulation by Ebola virus glycoprotein. Virology, 383: 237-247.

Francica JR, Varela-Rohena A, Medvec A, Plesa G, Riley JL, Bates P. 2010. Steric shielding of surface epitopes and impaired immune recognition induced by the ebola virus glycoprotein. 
PLoS Pathog, 6: e1001098.

Furuyama W, Marzi A, Nanbo A, Haddock E, Maruyama J, Miyamoto H, Igarashi M, Yoshida R, Noyori O, Feldmann H, Takada A. 2016. Discovery of an antibody for pan-ebolavirus therapy. Sci Rep, 6: 20514.

Gallaher WR, Garry RF. 2015. Modeling of the Ebola virus delta peptide reveals a potential lytic sequence motif. Viruses, 7: 285-305.

Geisbert TW, Hensley LE, Gibb TR, Steele KE, Jaax NK, Jahrling PB. 2000. Apoptosis induced in vitro and in vivo during infection by Ebola and Marburg viruses. Lab Invest, 80: 171-186.

Geisbert TW, Hensley LE, Larsen T, Young HA, Reed DS, Geisbert JB, Scott DP, Kagan E, Jahrling PB, Davis KJ. 2003. Pathogenesis of Ebola hemorrhagic fever in cynomolgus macaques: evidence that dendritic cells are early and sustained targets of infection. Am J Pathol, 163: 2347-2370.

Gong X, Qian H, Zhou X, Wu J, Wan T, Cao P, Huang W, Zhao X, Wang X, Wang P, Shi Y, Gao GF, Zhou Q, Yan N. 2016. Structural Insights into the Niemann-Pick C1 (NPC1)-Mediated Cholesterol Transfer and Ebola Infection. Cell, 165: 1467-1478.

Groseth A, Marzi A, Hoenen T, Herwig A, Gardner D, Becker S, Ebihara H, Feldmann H. 2012. The Ebola virus glycoprotein contributes to but is not sufficient for virulence in vivo. PLoS Pathog, 8: e1002847.

Gustin JK, Bai Y, Moses AV, Douglas JL. 2015. Ebola Virus Glycoprotein Promotes Enhanced Viral Egress by Preventing Ebola VP40 From Associating With the Host Restriction Factor BST2/Tetherin. J Infect Dis, 212 Suppl 2: S181-S190.

Hammonds J, Wang JJ, Yi H, Spearman P. 2010. Immunoelectron microscopic evidence for Tetherin/BST2 as the physical bridge between HIV-1 virions and the plasma membrane. PLoS Pathog, 6: e1000749.

Han Z, Boshra H, Sunyer JO, Zwiers SH, Paragas J, Harty RN. 2003. Biochemical and functional characterization of the Ebola virus VP24 protein: implications for a role in virus assembly and budding. J Virol, 77: 1793-1800.

Harty RN, Brown ME, Wang G, Huibregtse J, Hayes FP. 2000. A PPxY motif within the VP40 protein of Ebola virus interacts physically and functionally with a ubiquitin ligase: implications for filovirus budding. Proc Natl Acad Sci U S A, 97: 1387113876.

Hinz A, Miguet N, Natrajan G, Usami Y, Yamanaka H, Renesto P, Hartlieb B, McCarthy AA, Simorre JP, Gottlinger H, Weissenhorn W. 2010. Structural basis of HIV-1 tethering to membranes by the BST-2/tetherin ectodomain. Cell Host Microbe, 7: 314-323.

Howell KA, Qiu X, Brannan JM, Bryan C, Davidson E, Holtsberg FW, Wec AZ, Shulenin S, Biggins JE, Douglas R, Enterlein SG, Turner HL, Pallesen J, Murin CD, He S, Kroeker A, Vu H, Herbert AS, Fusco ML, Nyakatura EK, Lai JR, Keck ZY, Foung SK, Saphire EO, Zeitlin L, Ward AB, Chandran K, Doranz BJ, Kobinger GP, Dye JM, Aman MJ. 2016. Antibody Treatment of Ebola and Sudan Virus Infection via a Uniquely Exposed Epitope within the Glycoprotein Receptor-Binding Site. Cell Rep, 15: $1514-1526$.

Ito H, Watanabe S, Takada A, Kawaoka Y. 2001. Ebola virus glycoprotein: proteolytic processing, acylation, cell tropism, and detection of neutralizing antibodies. J Virol, 75: 1576-1580.

Iwasa A, Shimojima M, Kawaoka Y. 2011. sGP serves as a structural protein in Ebola virus infection. J Infect Dis, 204 Suppl 3: S897-S903.

Jeffers SA, Sanders DA, Sanchez A. 2002. Covalent modifications of the ebola virus glycoprotein. J Virol, 76: 12463-12472.

Jiang H, Wang J, Manicassamy B, Manicassamy S, Caffrey M, Rong L. 2009. The Role of the Charged Residues of the GP2
Helical Regions in Ebola Entry. Virol Sin, 24: 121-135.

Jouvenet N, Neil SJ, Zhadina M, Zang T, Kratovac Z, Lee Y, McNatt M, Hatziioannou T, Bieniasz PD. 2009. Broad-spectrum inhibition of retroviral and filoviral particle release by tetherin. J Virol, 83: 1837-1844.

Kaletsky RL, Francica JR, Agrawal-Gamse C, Bates P. 2009. Tetherin-mediated restriction of filovirus budding is antagonized by the Ebola glycoprotein. Proc Natl Acad Sci U S A, 106: 2886-2891.

Kindzelskii AL, Yang Z, Nabel GJ, Todd RF, 3rd, Petty HR. 2000. Ebola virus secretory glycoprotein (sGP) diminishes Fc gamma RB-to-CR3 proximity on neutrophils. J Immunol, 164: 953958.

Kortepeter MG, Bausch DG, Bray M. 2011. Basic clinical and laboratory features of filoviral hemorrhagic fever. J Infect Dis, 204 Suppl 3: S810-S816.

Kuhl A, Banning C, Marzi A, Votteler J, Steffen I, Bertram S, Glowacka I, Konrad A, Sturzl M, Guo JT, Schubert U, Feldmann H, Behrens G, Schindler M, Pohlmann S. 2011. The Ebola virus glycoprotein and HIV-1 Vpu employ different strategies to counteract the antiviral factor tetherin. J Infect Dis, 204 Suppl 3: S850-S860.

Kupzig S, Korolchuk V, Rollason R, Sugden A, Wilde A, Banting G. 2003. Bst-2/HM1.24 is a raft-associated apical membrane protein with an unusual topology. Traffic, 4: 694-709.

Le Tortorec A, Willey S, Neil SJ. 2011. Antiviral inhibition of enveloped virus release by tetherin/BST-2: action and counteraction. Viruses, 3: 520-540.

Lee JE, Fusco ML, Hessell AJ, Oswald WB, Burton DR, Saphire EO. 2008. Structure of the Ebola virus glycoprotein bound to an antibody from a human survivor. Nature, 454: 177-182.

Lee JE, Saphire EO. 2009. Ebolavirus glycoprotein structure and mechanism of entry. Future Virol, 4: 621-635.

Lennemann NJ, Rhein BA, Ndungo E, Chandran K, Qiu X, Maury W. 2014. Comprehensive functional analysis of N-linked glycans on Ebola virus GP1. MBio, 5: e00862-00813.

Lopez LA, Yang SJ, Exline CM, Rengarajan S, Haworth KG, Cannon PM. 2012. Anti-tetherin activities of HIV-1 Vpu and Ebola virus glycoprotein do not involve removal of tetherin from lipid rafts. J Virol, 86: 5467-5480.

Lopez LA, Yang SJ, Hauser H, Exline CM, Haworth KG, Oldenburg J, Cannon PM. 2010. Ebola virus glycoprotein counteracts BST-2/Tetherin restriction in a sequence-independent manner that does not require tetherin surface removal. J Virol, 84: 7243-7255.

Ma DY, Suthar MS. 2015. Mechanisms of innate immune evasion in re-emerging RNA viruses. Curr Opin Virol, 12: 26-37.

Mahanty S, Bray M. 2004. Pathogenesis of filoviral haemorrhagic fevers. Lancet Infect Dis, 4: 487-498.

Martines RB, Ng DL, Greer PW, Rollin PE, Zaki SR. 2015. Tissue and cellular tropism, pathology and pathogenesis of Ebola and Marburg viruses. J Pathol, 235: 153-174.

Martinez O, Tantral L, Mulherkar N, Chandran K, Basler CF. 2011. Impact of Ebola mucin-like domain on antiglycoprotein antibody responses induced by Ebola virus-like particles. J Infect Dis, 204 Suppl 3: S825-S832.

Martinez O, Valmas C, Basler CF. 2007. Ebola virus-like particleinduced activation of NF-kappaB and Erk signaling in human dendritic cells requires the glycoprotein mucin domain. Virology, 364: 342-354.

Mehedi M, Falzarano D, Seebach J, Hu X, Carpenter MS, Schnittler HJ, Feldmann H. 2011. A new Ebola virus nonstructural glycoprotein expressed through RNA editing. J Virol, 85: 54065414.

Messaoudi I, Amarasinghe GK, Basler CF. 2015. Filovirus patho- 
genesis and immune evasion: insights from Ebola virus and Marburg virus. Nat Rev Microbiol, 13: 663-676.

Misasi J, Gilman MS, Kanekiyo M, Gui M, Cagigi A, Mulangu S, Corti D, Ledgerwood JE, Lanzavecchia A, Cunningham J, Muyembe-Tamfun JJ, Baxa U, Graham BS, Xiang Y, Sullivan NJ, McLellan JS. 2016. Structural and molecular basis for Ebola virus neutralization by protective human antibodies. Science, 351: 1343-1346.

Mohan GS, Li W, Ye L, Compans RW, Yang C. 2012. Antigenic subversion: a novel mechanism of host immune evasion by Ebola virus. PLoS Pathog, 8: e1003065.

Mohan GS, Ye L, Li W, Monteiro A, Lin X, Sapkota B, Pollack BP, Compans RW, Yang C. 2015. Less is more: Ebola virus surface glycoprotein expression levels regulate virus production and infectivity. J Virol, 89: 1205-1217.

Moller-Tank S, Maury W. 2015. Ebola virus entry: a curious and complex series of events. PLoS Pathog, 11: e1004731.

Nakayama E, Saijo M. 2013. Animal models for Ebola and Marburg virus infections. Front Microbiol, 4: 267.

Ning YJ, Feng K, Min YQ, Cao WC, Wang M, Deng F, Hu Z, Wang H. 2015. Disruption of type I interferon signaling by the nonstructural protein of severe fever with thrombocytopenia syndrome virus via the hijacking of STAT2 and STAT1 into inclusion bodies. J Virol, 89: 4227-4236.

Ning YJ, Wang M, Deng M, Shen S, Liu W, Cao WC, Deng F, Wang YY, Hu Z, Wang H. 2014. Viral suppression of innate immunity via spatial isolation of TBK1/IKKepsilon from mitochondrial antiviral platform. J Mol Cell Biol, 6: 324-337.

Okumura A, Pitha PM, Yoshimura A, Harty RN. 2010. Interaction between Ebola virus glycoprotein and host toll-like receptor 4 leads to induction of proinflammatory cytokines and SOCS1. J Virol, 84: 27-33.

Pallesen J, Murin CD, de Val N, Cottrell CA, Hastie KM, Turner HL, Fusco ML, Flyak AI, Zeitlin L, Crowe JE, Jr., Andersen KG, Saphire EO, Ward AB. 2016. Structures of Ebola virus GP and sGP in complex with therapeutic antibodies. Nat Microbiol, 1: 16128 .

Panchal RG, Ruthel G, Kenny TA, Kallstrom GH, Lane D, Badie SS, Li L, Bavari S, Aman MJ. 2003. In vivo oligomerization and raft localization of Ebola virus protein VP40 during vesicular budding. Proc Natl Acad Sci U S A, 100: 15936-15941.

Perez-Caballero D, Zang T, Ebrahimi A, McNatt MW, Gregory DA, Johnson MC, Bieniasz PD. 2009. Tetherin inhibits HIV-1 release by directly tethering virions to cells. Cell, 139: 499-511.

Peters CJ, LeDuc JW. 1999. An introduction to Ebola: the virus and the disease. J Infect Dis, 179 Suppl 1: ix-xvi.

Qiu X, Wong G, Audet J, Bello A, Fernando L, Alimonti JB, Fausther-Bovendo H, Wei H, Aviles J, Hiatt E, Johnson A, Morton J, Swope K, Bohorov O, Bohorova N, Goodman C, Kim D, Pauly MH, Velasco J, Pettitt J, Olinger GG, Whaley K, $\mathrm{Xu}$ B, Strong JE, Zeitlin L, Kobinger GP. 2014. Reversion of advanced Ebola virus disease in nonhuman primates with ZMapp. Nature, 514: 47-53.

Radoshitzky SR, Warfield KL, Chi X, Dong L, Kota K, Bradfute SB, Gearhart JD, Retterer C, Kranzusch PJ, Misasi JN, Hogenbirk MA, Wahl-Jensen V, Volchkov VE, Cunningham JM, Jahrling PB, Aman MJ, Bavari S, Farzan M, Kuhn JH. 2011. Ebolavirus delta-peptide immunoadhesins inhibit marburgvirus and ebolavirus cell entry. J Virol, 85: 8502-8513.

Randall RE, Goodbourn S. 2008. Interferons and viruses: an interplay between induction, signalling, antiviral responses and virus countermeasures. J Gen Virol, 89: 1-47.

Reynard O, Borowiak M, Volchkova VA, Delpeut S, Mateo M, Volchkov VE. 2009. Ebolavirus glycoprotein GP masks both its own epitopes and the presence of cellular surface proteins. J Virol, 83: 9596-9601.

Ritchie G, Harvey DJ, Stroeher U, Feldmann F, Feldmann H, Wahl-Jensen V, Royle L, Dwek RA, Rudd PM. 2010. Identification of N-glycans from Ebola virus glycoproteins by matrixassisted laser desorption/ionisation time-of-flight and negative ion electrospray tandem mass spectrometry. Rapid Commun Mass Spectrom, 24: 571-585.

Rougeron V, Feldmann H, Grard G, Becker S, Leroy EM. 2015. Ebola and Marburg haemorrhagic fever. J Clin Virol, 64: 111119.

Sadler AJ, Williams BR. 2008. Interferon-inducible antiviral effectors. Nat Rev Immunol, 8: 559-568.

Sanchez A, Trappier SG, Mahy BW, Peters CJ, Nichol ST. 1996. The virion glycoproteins of Ebola viruses are encoded in two reading frames and are expressed through transcriptional editing. Proc Natl Acad Sci U S A, 93: 3602-3607.

Sanchez A, Yang ZY, Xu L, Nabel GJ, Crews T, Peters CJ. 1998. Biochemical analysis of the secreted and virion glycoproteins of Ebola virus. J Virol, 72: 6442-6447.

Sanchez AJ, Vincent MJ, Erickson BR, Nichol ST. 2006. Crimeancongo hemorrhagic fever virus glycoprotein precursor is cleaved by Furin-like and SKI-1 proteases to generate a novel 38-kilodalton glycoprotein. Journal of Virology, 80: 514-525.

Schneider WM, Chevillotte MD, Rice CM. 2014. Interferon-stimulated genes: a complex web of host defenses. Annu Rev Immunol, 32: 513-545.

Schnittler HJ, Feldmann H. 1998. Marburg and Ebola hemorrhagic fevers: does the primary course of infection depend on the accessibility of organ-specific macrophages? Clin Infect Dis, 27: 404-406.

Shurtleff AC, Bavari S. 2015. Animal models for ebolavirus countermeasures discovery: what defines a useful model? Expert Opin Drug Discov, 10: 685-702.

Simmons G, Wool-Lewis RJ, Baribaud F, Netter RC, Bates P. 2002. Ebola virus glycoproteins induce global surface protein down-modulation and loss of cell adherence. J Virol, 76: 2518 2528.

Singh G, Kumar A, Singh K, Kaur J. 2015. Ebola virus: an introduction and its pathology. Rev Med Virol. doi: 10.1002/rmv.1863.

Stark GR. 2007. How cells respond to interferons revisited: from early history to current complexity. Cytokine Growth Factor Rev, 18: 419-423.

Sui J, Marasco WA. 2002. Evidence against Ebola virus sGP binding to human neutrophils by a specific receptor. Virology, 303: 9-14.

Takada A. 2012. Filovirus tropism: cellular molecules for viral entry. Front Microbiol, 3: 34.

Takada A, Watanabe S, Ito H, Okazaki K, Kida H, Kawaoka Y. 2000. Downregulation of beta1 integrins by Ebola virus glycoprotein: implication for virus entry. Virology, 278: 20-26.

Tang H. 2016. Uncovering the mystery of Ebola virus entry: Lock and key. Sci China Life Sci, 59: 434-435.

To KK, Chan JF, Tsang AK, Cheng VC, Yuen KY. 2015. Ebola virus disease: a highly fatal infectious disease reemerging in West Africa. Microbes Infect, 17: 84-97.

Tokarev A, Skasko M, Fitzpatrick K, Guatelli J. 2009. Antiviral activity of the interferon-induced cellular protein BST-2/tetherin. AIDS Res Hum Retroviruses, 25: 1197-1210.

U.S. Centers for Disease Control and Prevention. 2016a. 2014 Ebola outbreak in West Africa-case counts. Available: http:// www.cdc.gov/vhf/ebola/outbreaks/2014-west-africa/casecounts.html. Accessed: April 14, 2016.

U.S. Centers for Disease Control and Prevention. 2016b. Cost of 
the Ebola epidemic. Available: http:/www.cdc.gov/vhf/ebola/ outbreaks/2014-west-africa/cost-of-ebola.html. Accessed: May 3, 2016.

Van Damme N, Goff D, Katsura C, Jorgenson RL, Mitchell R, Johnson MC, Stephens EB, Guatelli J. 2008. The interferon-induced protein BST-2 restricts HIV-1 release and is downregulated from the cell surface by the viral Vpu protein. Cell Host Microbe, 3: 245-252.

Vande Burgt NH, Kaletsky RL, Bates P. 2015. Requirements within the Ebola Viral Glycoprotein for Tetherin Antagonism. Viruses, 7: 5587-5602.

Volchkov VE. 1999. Processing of the Ebola virus glycoprotein. Curr Top Microbiol Immunol, 235: 35-47.

Volchkov VE, Becker S, Volchkova VA, Ternovoj VA, Kotov AN, Netesov SV, Klenk HD. 1995. GP mRNA of Ebola virus is edited by the Ebola virus polymerase and by $\mathrm{T} 7$ and vaccinia virus polymerases. Virology, 214: 421-430.

Volchkov VE, Blinov VM, Netesov SV. 1992. The envelope glycoprotein of Ebola virus contains an immunosuppressive-like domain similar to oncogenic retroviruses. FEBS Lett, 305: 181184.

Volchkov VE, Feldmann H, Volchkova VA, Klenk HD. 1998a. Processing of the Ebola virus glycoprotein by the proprotein convertase furin. Proc Natl Acad Sci U S A, 95: 5762-5767.

Volchkov VE, Volchkova VA, Muhlberger E, Kolesnikova LV, Weik M, Dolnik O, Klenk HD. 2001. Recovery of infectious Ebola virus from complementary DNA: RNA editing of the GP gene and viral cytotoxicity. Science, 291: 1965-1969.

Volchkov VE, Volchkova VA, Slenczka W, Klenk HD, Feldmann H. 1998b. Release of viral glycoproteins during Ebola virus infection. Virology, 245: 110-119.

Volchkova VA, Klenk HD, Volchkov VE. 1999. Delta-peptide is the carboxy-terminal cleavage fragment of the nonstructural small glycoprotein sGP of Ebola virus. Virology, 265: 164-171.

Wahl-Jensen V, Kurz SK, Hazelton PR, Schnittler HJ, Stroher U, Burton DR, Feldmann H. 2005a. Role of Ebola virus secreted glycoproteins and virus-like particles in activation of human macrophages. J Virol, 79: 2413-2419.

Wahl-Jensen VM, Afanasieva TA, Seebach J, Stroher U, Feldmann H, Schnittler HJ. 2005b. Effects of Ebola virus glycoproteins on endothelial cell activation and barrier function. J Virol, 79: 10442-10450.

Wang H, Shi Y, Song J, Qi J, Lu G, Yan J, Gao GF. 2016. Ebola Viral Glycoprotein Bound to Its Endosomal Receptor Niemann-
Pick C1. Cell, 164: 258-268

Wang J, Manicassamy B, Caffrey M, Rong L. 2011. Characterization of the receptor-binding domain of Ebola glycoprotein in viral entry. Virol Sin, 26: 156-170.

Wec AZ, Nyakatura EK, Herbert AS, Howell KA, Holtsberg FW, Bakken RR, Mittler E, Christin JR, Shulenin S, Jangra RK, Bharrhan S, Kuehne AI, Bornholdt ZA, Flyak AI, Saphire EO, Crowe JE, Jr., Aman MJ, Dye JM, Lai JR, Chandran K. 2016. A "Trojan horse" bispecific antibody strategy for broad protection against ebolaviruses. Science. pii: aag3267.

Wertheim JO, Worobey M. 2009. Relaxed selection and the evolution of RNA virus mucin-like pathogenicity factors. J Virol, 83: 4690-4694.

White JM, Whittaker GR. 2016. Fusion of Enveloped Viruses in Endosomes. Traffic, 17: 593-614.

Wilson JA, Hevey M, Bakken R, Guest S, Bray M, Schmaljohn AL, Hart MK. 2000. Epitopes involved in antibody-mediated protection from Ebola virus. Science, 287: 1664-1666.

Wool-Lewis RJ, Bates P. 1999. Endoproteolytic processing of the ebola virus envelope glycoprotein: cleavage is not required for function. J Virol, 73: 1419-1426.

Yaddanapudi K, Palacios G, Towner JS, Chen I, Sariol CA, Nichol ST, Lipkin WI. 2006. Implication of a retrovirus-like glycoprotein peptide in the immunopathogenesis of Ebola and Marburg viruses. Faseb Journal, 20: 2519-2530.

Yang ZY, Duckers HJ, Sullivan NJ, Sanchez A, Nabel EG, Nabel GJ. 2000. Identification of the Ebola virus glycoprotein as the main viral determinant of vascular cell cytotoxicity and injury. Nat Med, 6: 886-889.

Ye J, Zhu B, Fu ZF, Chen H, Cao S. 2013. Immune evasion strategies of flaviviruses. Vaccine, 31: 461-471.

Ye L, Lin JG, Sun YL, Bennouna S, Lo M, Wu QY, Bu ZG, Pulendran B, Compans RW, Yang CL. 2006. Ebola virus-like particles produced in insect cells exhibit dendritic cell stimulating activity and induce neutralizing antibodies. Virology, 351 260-270.

Zaki SR, Goldsmith CS. 1999. Pathologic features of filovirus infections in humans. Curr Top Microbiol Immunol, 235: 97-116.

Zhao D, Han X, Zheng X, Wang H, Yang Z, Liu D, Han K, Liu J, Wang X, Yang W, Dong Q, Yang S, Xia X, Tang L, He F. 2016. The Myeloid LSECtin Is a DAP12-Coupled Receptor That Is Crucial for Inflammatory Response Induced by Ebola Virus Glycoprotein. PLoS Pathog, 12: e1005487. 